\title{
Hypsodonty and tooth facet development in relation to diet and habitat in herbivorous ungulates: implications for understanding tooth wear
}

\author{
Kaiser, Thomas M ; Müller, Dennis W H ; Fortelius, Mikael ; Schulz, Ellen ; Codron, Daryl ; Clauss, \\ Marcus
}

\begin{abstract}
The evolution of high-crowned teeth or hypsodonty in herbivorous mammals is widely interpreted as a species-specific adaptation to increasingly wear-inducing diets and environments at evolutionary time scales, with internal abrasives (such as phytoliths in grasses) and/or external abrasives (such as dust or grit) as putative causative factors. The mesowear score (MS) instead describes tooth wear experienced by individual animals during their lifetime. 2. Under the assumption that the abrasiveness that causes the MS in individuals is the same abrasiveness to which species adapted by evolving hypsodonty, one would expect a close correlation between the MS and the hypsodonty index (HI). Alternatively, if these two measures reflect different aspects of wear, one would expect differences in the way that proxies of diet or environment/climate correlate with each parameter. 3 . In order to test these hypotheses, we collated a dataset on the HI, MS, percentage of grass in the natural diet (\%grass), habitat (open, intermediate, closed) and annual precipitation (PREC) in extant mammalian herbivores. The availability of a quantitative MS constrained the dataset to 75 species. Data were analysed with and without phylogenetic generalized least squares (PGLS). 4. Correlations with PREC were stronger for HI than for MS, whereas correlations with \%grass were similar for HI and MS. Habitat had a significant influence on the relationship with \%grass for HI but not for MS. Habitat also had a significant influence on the relationship between HI and MS. MS improved the predictive power of HI for \%grass, but not for PREC. 5. These results suggest that while the MS indicates predominantly the wear effect of the diet (internal abrasives), HI represents an adaptation to a wear effect that comprises both diet and environment (external abrasives). The additional environmental wear effect must reduce tooth height without causing macroscopic changes in tooth facet development as described by the MS. 6 . The most parsimonious explanation for the apparent discrepancy between HI and MS is that external abrasives of very fine particle size play a major role in naturally occurring tooth wear. The experimental testing of this hypothesis will enhance our understanding of the processes involved in tooth wear.
\end{abstract}

DOI: https://doi.org/10.1111/j.1365-2907.2011.00203.x

Posted at the Zurich Open Repository and Archive, University of Zurich ZORA URL: https://doi.org/10.5167/uzh-69097

Journal Article

Originally published at:

Kaiser, Thomas M; Müller, Dennis W H; Fortelius, Mikael; Schulz, Ellen; Codron, Daryl; Clauss, Marcus (2013). Hypsodonty and tooth facet development in relation to diet and habitat in herbivorous ungulates: implications for understanding tooth wear. Mammal Review, 43(1):34-46.

DOI: https://doi.org/10.1111/j.1365-2907.2011.00203.x 


\section{Hypsodonty and tooth facet development in relation to diet and habitat in herbivorous ungulates: implications for understanding tooth wear}

Thomas M. KAISER Biocentre Grindel and Zoological Museum, University Hamburg, Martin-Luther-King-Platz 3, D-20146 Hamburg, Germany. E-mail: thomas.kaiser@uni-hamburg.de Dennis W. H. MÜLLER Clinic for Zoo Animals, Exotic Pets and Wildlife, Vetsuisse Faculty, University of Zurich, Winterthurerstr. 260, 8057 Zurich, Switzerland. E-mail: dennis.mueller@npv-bw.bayern.de Mikael FORTELIUS Department of Geosciences and Geography, University of Helsinki, PO Box 64 (Gustaf Hällströmin katu 2a), FIN-00014 Helsinki, Finland. E-mail: mikael.fortelius@helsinki.fi Ellen SCHULZ Biocentre Grindel and Zoological Museum, University Hamburg, Martin-Luther-King-Platz 3, D-20146 Hamburg, Germany. E-mail: ellen.schulz@uni-hamburg.de Daryl CODRON Clinic for Zoo Animals, Exotic Pets and Wildlife, Vetsuisse Faculty, University of Zurich, Winterthurerstr. 260, 8057 Zurich, Switzerland. E-mail: dcodron@vetclinics.uzh.ch Marcus CLAUSS* Clinic for Zoo Animals, Exotic Pets and Wildlife, Vetsuisse Faculty, University of Zurich, Winterthurerstr. 260, 8057 Zurich, Switzerland. E-mail: mclauss@vetclinics.uzh.ch

\section{Keywords}

Antidorcas marsupialis, Antilocapra americana, dental adaptation, evolution, feeding

\section{${ }^{*}$ Correspondence author.}

Submitted: 8 June 2011

Returned for revision: 3 August 2011

Revision accepted: 6 September 2011

Editor: $\mathrm{KH}$

doi:10.1111/j.1365-2907.2011.00203.x

\begin{abstract}
1. The evolution of high-crowned teeth or hypsodonty in herbivorous mammals is widely interpreted as a species-specific adaptation to increasingly wear-inducing diets and environments at evolutionary time scales, with internal abrasives (such as phytoliths in grasses) and/or external abrasives (such as dust or grit) as putative causative factors. The mesowear score (MS) instead describes tooth wear experienced by individual animals during their lifetime.

2. Under the assumption that the abrasiveness that causes the MS in individuals is the same abrasiveness to which species adapted by evolving hypsodonty, one would expect a close correlation between the MS and the hypsodonty index (HI). Alternatively, if these two measures reflect different aspects of wear, one would expect differences in the way that proxies of diet or environment/climate correlate with each parameter.

3. In order to test these hypotheses, we collated a dataset on the HI, MS, percentage of grass in the natural diet (\%grass), habitat (open, intermediate, closed) and annual precipitation (PREC) in extant mammalian herbivores. The availability of a quantitative MS constrained the dataset to 75 species. Data were analysed with and without phylogenetic generalized least squares.

4. Correlations with PREC were stronger for HI than for MS, whereas correlations with \%grass were similar for HI and MS. Habitat had a significant influence on the relationship with \%grass for HI but not for MS. Habitat also had a significant influence on the relationship between HI and MS. MS improved the predictive power of HI for \%grass, but not for PREC.

5. These results suggest that while the MS indicates predominantly the wear effect of the diet (internal abrasives), HI represents an adaptation to a wear effect that comprises both diet and environment (external abrasives). The additional environmental wear effect must reduce tooth height without causing macroscopic changes in tooth facet development as described by the MS.
\end{abstract}


6. The most parsimonious explanation for the apparent discrepancy between HI and MS is that external abrasives of very fine particle size play a major role in naturally occurring tooth wear. The experimental testing of this hypothesis will enhance our understanding of the processes involved in tooth wear.

\section{INTRODUCTION}

Among various dental adaptations that especially herbivorous mammals are known for (Reilly et al. 2001, Fritz et al. 2009), variations in molar crown height, or hypsodonty, is one of the best documented (Van Valen 1960, Fortelius 1985, Janis 1988, Janis \& Fortelius 1988, Mendoza \& Palmqvist 2008, Damuth \& Janis 2011). Examples of teeth varying in their hypsodonty are depicted in Fig. 1. Hypsodont teeth have a very high tooth crown, mesodont teeth have an intermediate tooth crown, and brachydont teeth have a comparatively low crown height. As a quantitative measure of hypsodonty, the hypsodonty index (HI) was defined by Janis (1988) as the height of the unworn M3 crown divided by the occlusal width of the same tooth. The intuitive interpretation of hypsodonty is that it represents an adaptation to a high rate of tooth wear (incremental removal of dental tissue), effected by intrinsic properties of the ingested food, by exogenous attachments to it, or by both (Fortelius 1985, Janis \& Fortelius 1988, Damuth \& Janis 2011). The intrinsic properties are either abrasive particles such as phytoliths or forage qualities such as toughness or nutritive value (fibre content and fibre type) that affect the chewing process, while the exogenous matter is thought to be mainly dust or grit ingested together with the forage. There is a recent debate in the scientific literature (Sanson et al. 2007, Damuth \& Janis 2011) on whether intrinsic properties or extrinsic abrasives play the more important role in the evolution of hypsodonty; the relative timing of the occurrence of grasslands and hypsodont molars in North American equids is a major bone of contention (Strömberg 2006). Demonstrated correlations of the HI with calculated tooth wear rates (Solounias et al. 1994) and with the level of abrasives measured in faeces (Hummel et al. 2011) provide some insight but cannot resolve this dilemma.

The HI has repeatedly been shown to correlate with the proportion of grass in the natural diet (reviewed in Clauss et al. 2008), with proxies that indicate diet quality and possibly low or tall grass feeding (Codron et al. 2007, 2008), with the openness of the habitat (Mendoza \& Palmqvist 2008) and with annual precipitation (Damuth \& Fortelius 2001, Damuth et al. 2002, Fortelius et al. 2002, Eronen et al. $2010 \mathrm{a}, \mathrm{b})$. In an analysis of variance (ANOVA) in 133 extant ungulate species, Damuth and Janis (2011) found independent significant effects of both diet and habitat categories on HI, supporting the concept that HI should not be con- (a)
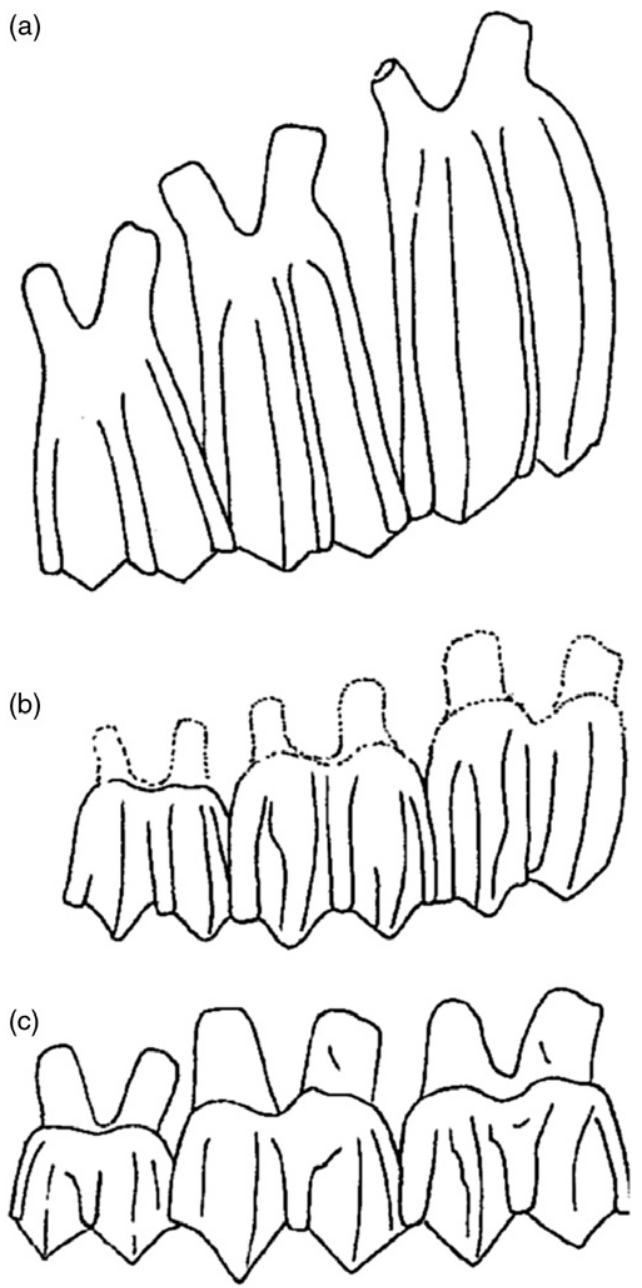

Fig. 1. Examples of hypsodont, mesodont and brachydont molars, from (a) goat Capra hircus (hypsodont); (b) Cervus duvaucellii (mesodont); and (c) white-tailed deer Odocoileus virginianus (brachydont; figure and legend from Fortelius \& Solounias 2000).

sidered a response to intrinsic food properties alone. The wear properties of natural diets (of different botanical groups and from different geographical or climatic origins) have so far not been investigated, and conclusions based on the HI must therefore be considered no more than wellfounded hypotheses awaiting testing.

The description of the macroscopic effect of tooth wear by means of the mesowear method was introduced by Fortelius and Solounias (2000) and Kaiser et al. (2000) and 
(b)

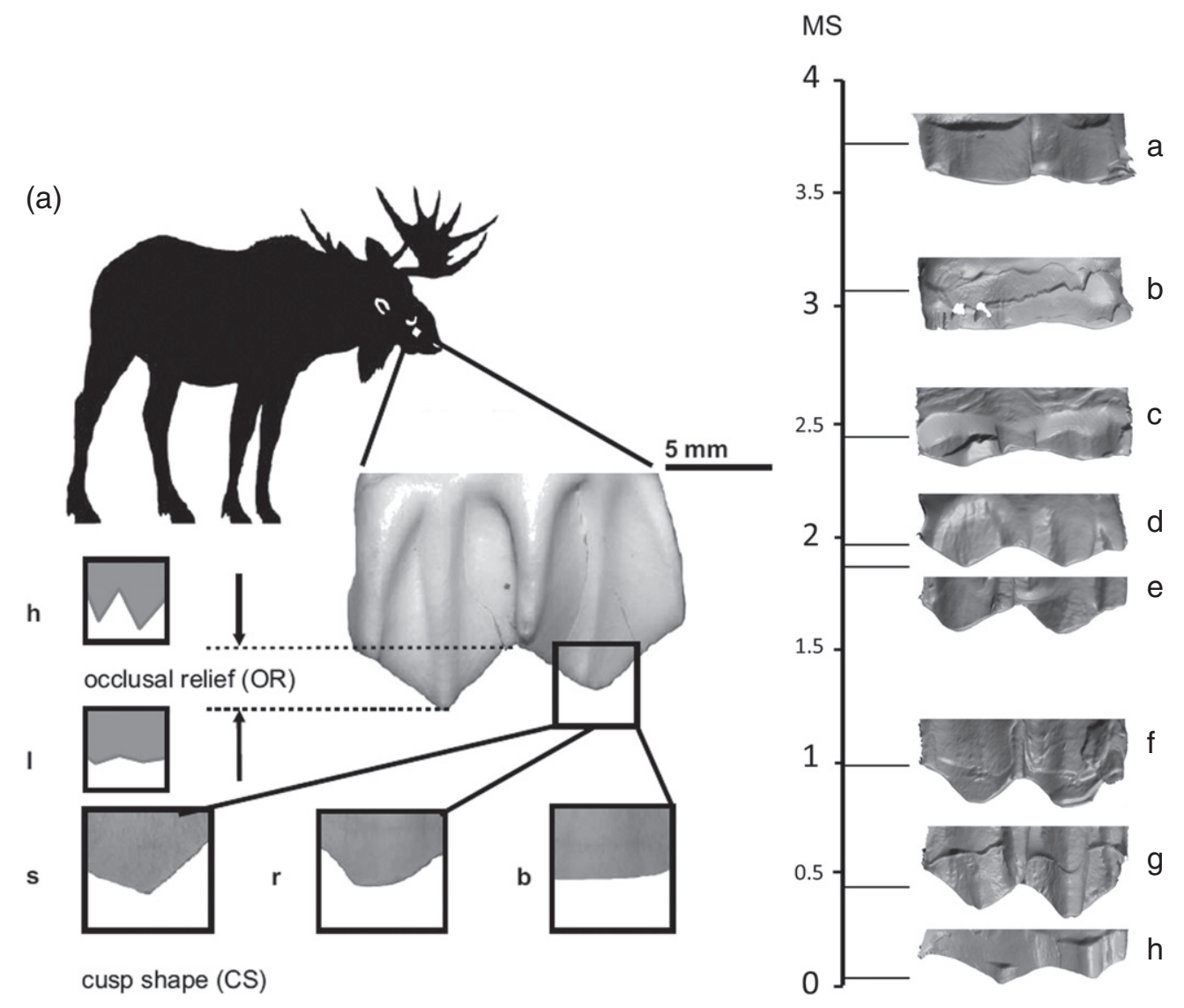

Fig. 2. (a) Mesowear scoring of the molar relief (into 'low' or 'high') and cusp shape (into 'sharp', 'rounded' or 'blunt') from Kaiser et al. (2009); this information is transferred into a quantitative score. Note that scoring of relief is not absolute among all species studied, but in relation to the taxonomic group of animals from which the molar under inspection originated. (b) Examples of mesowear scores (MS) from Kaiser et al. (2009) and Kaiser (2011). Typical buccal aspects of upper molar apices illustrate (a) Bison bison (NMW-5540); (b) Ceratotherium simum (ZMH-2552); (c) Equus grevyi (ZMH-7103); (d) Rangifer tarandus (SAL-118); (e) Connochaetes taurinus (ZMH-6774); (f) Aepyceros melampus (ZMH-5687); (g) Giraffa camelopardalis (NMW-312149); and (h) Diceros bicornis (ZMH-1865) as 3-D models of high-resolution dental casts; not to scale. Note that (a) to (h) cannot be used as visual templates to translate mesowear into a MS. NMW Natural History Museum Vienna (Mammalogy); ZMH Zoological Museum Hamburg; SAL Braunschweig State Museum (Wolfenbüttel).

has been applied to a very large number of extant and fossil species. This method is based on the empirical observation of two 'modes' of tooth wear, attrition and abrasion (Fortelius 1985). Mesowear scoring first requires categorization of the tooth occlusal relief into 'high' or 'low' and the cusp shape into 'sharp', 'rounded' or 'blunt' (Fig. 2a). Traditionally, species have been characterized by the percentage of these findings in a given sample of scored teeth. The quasiplanar wear facets of the occlusal surfaces (leading to sharp cusps) are attributed to attrition, while rounded surfaces that encroach on the facets are attributed to abrasion. Other potential explanations, such as differences in the consistency of jaw movements during chewing (a hypothesis outlined in Kaiser et al. 2010), have so far not been investigated in relation to mesowear. In the conventional view, attrition was thought to reflect mainly wear resulting from direct contact between occluding tooth surfaces, while abrasion was thought to arise from hard particles trapped between them and impacted into the dental enamel during chewing.

In a departure from this conventional view, Fortelius (1987) presented a theoretical argument for all dental wear to be caused mainly by particles distributed within the chewed food bolus. This argument was based on scaling considerations arising from the empirical observation that tooth size is broadly isometric (geometrically similar) across the full range of mammal sizes (Fortelius 1985, 1988), i.e. tooth volume scales directly with body mass $\left(\mathrm{BM}^{1.0}\right.$ or isometrically). If food intake scales at $\mathrm{BM}^{0.75}$ and longevity at $\mathrm{BM}^{0.25}$, then lifetime food intake (the product of the two latter parameters) should also scale more or less isometri- 
cally (as $\mathrm{BM}^{0.75} \times \mathrm{BM}^{0.25}=\mathrm{BM}^{1.0}$ ). Tooth wear should therefore also scale isometrically with BM. The amount (volume) of dental tissue removed by tooth wear can be estimated as the product of occlusal surface length (scaling to $\mathrm{BM}^{0.33}$ ), occlusal surface width (scaling to $\mathrm{BM}^{0.33}$ ), and the depth of the tissue layer that is removed (also scaling to $\mathrm{BM}^{0.33}$ according to the logic implicit in the argument); the product would thus scale to $\mathrm{BM}^{0.33+0.33+0.33=1.0}$, or isometrically. Such scaling does not appear to be compatible with wear caused by pure tooth-to-tooth contact, in which a given chewing stress (which is constant for a given food) would remove layers of equal depth in different-sized teeth (i.e., the depth of the tissue layer removed would not scale at all, but be a constant). Given isometric scaling of tooth size, tooth wear thus cannot mainly be caused by surface tooth-to-tooth contact, but must instead be related to the volume of food, which, as stated above, scales isometrically with BM per unit lifetime. This finally leads to the conclusion that some characteristic of the food - most likely the presence of abrasive particles - is the main driver of tooth wear. This general argument does not necessarily exclude a minor role for direct tooth contact in shaping wear facets. Indeed, tooth-to-tooth contact must occur during chewing, given the fact that tough foods are cut by opposing tooth surfaces, and it seems unavoidable that it also causes some amount of wear. Additionally, the force required per volume food (chewing stress) might not be constant but may increase in animals of increasing body size, if food quality declines with body size (or if fibre levels in the food increase with body size; Owen-Smith 1988).

Regardless of the cause, the appearance of the wear facets on molar teeth is considered to correlate with the level of abrasiveness of the diet (the amount of attrition relative to abrasion); grazers have abrasion-dominated wear surfaces, whereas those of browsers are more attrition dominated. Components of the mesowear signal have been found to correlate with precipitation measurements for geographically distinct populations of a model species (Kaiser \& Schulz 2006), and the signal has also been used for climate reconstruction (Kaiser \& Rössner 2007, Rivals et al. 2008). The mesowear signal is not stable during ontogeny, and ontogenetic variation is more pronounced in brachydont species (Fortelius \& Solounias 2000, Rivals et al. 2007). Analyses that include the mesowear signal are usually less straightforward than simple correlations because in its original version, the mesowear signal is composed of a set of categorical data (Fortelius \& Solounias 2000). Various analyses have shown differences in the mesowear signal between feeding types, and, more recently, several researchers have developed approaches to convert the mesowear signal into a single continuous variable (Mihlbachler \& Solounias 2006, Rivals \& Semprebon 2006, Semprebon \& Rivals 2007, Kaiser et al. 2009), which is termed the mesowear score (MS). Examples of such scores are given in Fig. 2b. To our knowledge, the MS has, so far, not been tested statistically for a correlation with diet, habitat or precipitation (but see Fraser \& Theodor 2011 for a univariate comparison of the MS with the three major categorical feeding types: browsers, mixed feeders, grazers).

A main conclusion of the original mesowear study (Fortelius \& Solounias 2000) was that if the absolute amount of wear increases (as inferred from the HI), so does the distinctness of the pattern of wear (as measured by variation in MS), implying that both attrition and abrasion can in principle contribute equally to high wear rates. This still leaves open the question whether all tooth wear in fact registers in the MS, or whether there exists an additional component of wear that may remove tooth material without changing the MS. One possibility to explore this question is to compare the $\mathrm{HI}$ and the MS directly. Under the assumption that the abrasiveness that causes the MS in individuals is the same abrasiveness to which species adapted by evolving the HI, one expects a close correlation between the two measures. If, however, the two measures are not closely correlated, this may be due either to a mismatch between the historical conditions under which HI evolved and the actual conditions under which the observed MS developed, or to different mechanisms of tooth wear being recorded by these two measurements.

Direct comparisons of HI and MS are rare, and have so far, to our knowledge, been restricted to fossil assemblages or few extant taxa. Mihlbachler and Solounias (2006) compared an aspect of the mesowear signal to crown height in oreodont molars, but did not find a correlation after correcting for phylogeny; Mihlbachler et al. (2011) compared the MS and a measure similar to the HI in fossil and extant equids, and found a highly significant correlation (without accounting for phylogeny). Semprebon and Rivals (2007) plotted MS vs. HI data to demonstrate the outlier position of pronghorns Antilocapra americana (without statistical analysis). Here, we collated data on HI, MS as well as dietary and habitat proxies for a dataset of 75 extant large herbivores, in order to investigate the association between these measurements.

\section{METHODS}

Data on the HI were taken from Janis (1988). Data on the MS were calculated according to Kaiser et al. (2009) and Kaiser (2011), where the mesowear signal for each individual is translated to one ordinal variable ranging from 0 to 4 ; the MS of a species is then calculated as the average of all available dental individuals. The original dataset of Fortelius and Solounias (2000) was used for this calculation, as well as data on additional species available from the database of TMK. Each species was assigned a BM and a per- 
centage of grass in the natural diet (\%grass) as a continuous variable available from data collections by MC and from other publications, a categorical habitat variable (open, intermediate, closed) taken from Mendoza and Palmqvist (2008), and data on the mean annual precipitation (PREC) allocated to the species in the PanTHERIA database (Jones et al. 2009). The dataset used and the sources are given in Table 1.

Parameters were tested by ANOVA (with Sidak post hoc tests) and general linear models (GLM) using ordinary least squares (OLS) in PASP v. 18.0 (SPSS Inc., Chicago, Illinois, USA); normal distributions of residuals were tested to check the assumptions of GLM. Prior to analyses, both BM and MS were log transformed. In order to account for ancestrybased correlations in the datasets (i.e. finding a significant similarity simply because species are closely related; Felsenstein 1985, Pagel 1999), the data were controlled for phylogenetic influences using the 'phylogenetic generalized leastsquares' method (PGLS; Martins \& Hansen 1997, Rohlf 2001) in COMPARE v. 4.6 (Martins 2004). This procedure estimates a covariance matrix of the species due to their ancestral roots and includes these interrelationships in a generalized least squares algorithm to determine the model parameters. The phylogenetic trees for the two datasets were derived by pruning the mammal supertree from BinindaEmonds et al. (2007) for those species not represented in the datasets, using MESQUITE v. 2.74 (Maddison \& Maddison 2006). Because the resulting trees were not based on our own calculations of branch lengths using consistently the same characters, we used trees without branch lengths. The resulting phylogenetic tree is shown in Fig. 3. The significance level was set to 0.05 .

\section{RESULTS}

In our dataset, there was a positive correlation between BM and HI using OLS $\left(r^{2}=0.10, P=0.007\right)$, but not in PGLS $\left(r^{2}=0.01, P=0.427\right)$, indicating that the sample was biased in the taxonomic distribution of species across the body size range. There was no correlation between $\mathrm{BM}$ and the MS in either analysis (OLS: $r^{2}=0.00, P=0.964$; PGLS: $r^{2}=0.00$, $P=0.590)$. Both the $\mathrm{HI}$ and the MS were significantly correlated to the percentage of grass in the natural diet (\%grass; Fig. 4a; HI OLS: $r^{2}=0.40, P<0.001$; PGLS: $r^{2}=0.24, P<0.001$; MS OLS: $r^{2}=0.33, P<0.001$; PGLS: $\left.r^{2}=0.31, P<0.001\right)$. Note that while the regression coefficient was higher for HI than for MS in OLS, it was more similar for the two measurements in PGLS, indicating again a sampling bias in the taxonomic distribution of species across the body size and \%grass range.

Both HI and MS differed significantly between habitat categories [categorical variables only tested in OLS; HI: ANOVA $P<0.001$; Sidak post hoc tests with significant dif- ferences in $\mathrm{HI}$ between closed and intermediate $(P<0.001)$, closed and open $(P<0.001)$ but not between intermediate and open $(P=0.063)$ habitats; MS: ANOVA $P=0.003$; Sidak post hoc tests with significant differences in MS between closed and open $(P=0.003)$ but not between closed and intermediate $(P=0.139)$ or intermediate and open $(P=0.284)$ habitats]. Whereas the HI (dependent variable) was significantly correlated to the mean annual precipitation (PREC; OLS: $r^{2}=0.14, \quad P=0.001$; PGLS $\left.r^{2}=0.11, P=0.004\right)$, this relationship only tended towards significance for the MS, with a very shallow slope (OLS: $r^{2}=0.05, P=0.067$; PGLS $r^{2}=0.05, P=0.066$; Fig. 4b).

The correlation between the HI and the MS was highly significant (OLS: $r^{2}=0.21, \quad P<0.001 ;$ PGLS $r^{2}=0.11$, $P=0.004$; Fig. 5a). Among the ruminants, barasingha Rucervus duvauceli and reindeer Rangifer tarandus had particularly low HI for their high MS, and pronghorn, springbok Antidorcas marsupialis, impala Aepyceros melampus and ibex Capra ibex had particularly high HI for their low MS (Fig. 5b).

When habitat was included in GLMs, it was a significant cofactor (OLS: $P=0.001$; PGLS: $P=0.013$ ) in the relationship between HI (dependent variable) and \%grass (OLS: adjusted $r^{2}=0.49$ as compared to $r^{2}=0.40$ without habitat as a cofactor; Fig. 6a), consistent with results from the cluster analyses of Fortelius and Solounias (2000), and with unpublished results from Damuth and Janis (2011). In contrast, it did not significantly contribute (OLS: $P=0.656$; PGLS: $P=0.677$ ) to the relationship between MS (dependent variable) and \%grass (OLS: adjusted $r^{2}=0.32$ as compared to $r^{2}=0.33$ without habitat as a cofactor; Fig. $6 \mathrm{~b}$ ).

When precipitation was included as a covariate in GLMs, it had a significant effect on the relationship between $\mathrm{HI}$ (dependent variable) and \%grass in OLS but not in PGLS (OLS: $P=0.0189$, PGLS: $P=0.100$; OLS: adjusted $r^{2}=0.44$ as compared to $r^{2}=0.40$ without PREC as a covariable). PREC did not contribute significantly to the relationship between MS and \%grass in either model (OLS: $P=0.651$, PGLS $P=0.642$; OLS: adjusted $r^{2}=0.32$ as compared to $r^{2}=0.33$ without PREC as a covariable). The relationship between HI (dependent variable) and MS (independent variable) increased in regression coefficient when habitat (OLS: $P<0.001$, PGLS $P=0.002$ ) was included as a cofactor (OLS: adjusted $r^{2}=0.42$ as compared to $r^{2}=0.21$ without habitat as cofactor; Fig. 7), or when PREC (OLS: $P=0.004$, PGLS: $P=0.012$ ) was included as a covariable (OLS: adjusted $r^{2}=0.29$ as compared to $r^{2}=0.21$ without PREC as a covariable).

Finally, we changed the dependent variable to simulate a prediction of \%grass or precipitation by the use of the HI. Because of the collinearity between HI and MS, including both as independent variables in the same model will lead to spurious results, but this practice mimics the double use of $\mathrm{HI}$ and MS in approaches where diet or precipitation of a fossil 
Table 1. Data used in this study: species, body mass (BM), mesowear score (MS), hypsodonty index (HI), percentage of grass in the natural diet, habitat categories (HAB) and mean annual precipitation at the centre of distribution of the species (PREC)

\begin{tabular}{|c|c|c|c|c|c|c|c|c|c|c|}
\hline \multirow[b]{2}{*}{ Species } & & \multirow{2}{*}{$\begin{array}{l}\mathrm{BM} \\
\mathrm{kg}\end{array}$} & \multicolumn{3}{|c|}{ Mesowear } & \multirow[t]{2}{*}{$\mathrm{HI}$} & \multicolumn{2}{|l|}{ Grass } & \multirow[t]{2}{*}{$\mathrm{HAB}$} & \multirow{2}{*}{$\begin{array}{l}\text { PREC } \\
\mathrm{mm}\end{array}$} \\
\hline & & & MS & $n$ & Source & & $\%$ & Source & & \\
\hline Bison & Bison bison & 611 & 3.73 & 15 & 1 & 4.87 & 84 & 3 & 1 & 33.59 \\
\hline African buffalo & Syncerus caffer & 496 & 1.17 & 72 & 1,2 & 3.82 & 90 & 3 & 2 & 100.45 \\
\hline Nilgai & Boselaphus tragocamelus & 200 & 1.27 & 15 & 1 & 3.03 & 29 & 3 & 2 & 86.66 \\
\hline Four-horned antelope & Tetracerus quadricornis & 22.7 & 0.90 & 21 & 1 & 3.77 & 9 & 3 & 2 & 78.16 \\
\hline Eland & Taurotragus oryx & 511 & 0.45 & 42 & 1,2 & 2.91 & 20 & 6 & 2 & 76.46 \\
\hline Greater kudu & Tragelaphus strepsiceros & 196 & 1.00 & 7 & 1 & 2.29 & 5 & 3 & 2 & 61.83 \\
\hline Lesser kudu & Tragelaphus imberbis & 91.5 & 0.42 & 31 & 1 & 2.18 & 10 & 3 & 2 & 50.25 \\
\hline Nyala & Tragelaphus angasii & 93.3 & 0.65 & 20 & 1 & 2.52 & 20 & 3 & 2 & 65.29 \\
\hline Bongo & Tragelaphus eurycerus & 205 & 0.64 & 33 & 1,2 & 1.92 & 20 & 3 & 3 & 143.55 \\
\hline Bushbuck & Tragelaphus scriptus & 48 & 0.54 & 50 & 1,2 & 2.54 & 10 & 3 & 2 & 94.18 \\
\hline Bay duiker & Cephalophus dorsalis & 21 & 1.07 & 28 & 1 & 1.15 & 0 & 3 & 3 & 151.81 \\
\hline Yellow-backed duiker & Cephalophus sylvicultor & 65.4 & 1.46 & 39 & 1 & 2.23 & 1 & 5 & 2 & 132.7 \\
\hline Gemsbok & Oryx gazella & 200 & 1.00 & 3 & 2 & 3.37 & 82 & 3 & 1 & 40.73 \\
\hline Roan antelope & Hippotragus equinus & 241 & 1.29 & 31 & 1,2 & 4.28 & 85 & 3 & 1 & 89.35 \\
\hline Sable antelope & Hippotragus niger & 181 & 1.58 & 24 & 1,2 & 3.77 & 93 & 3 & 2 & 80.83 \\
\hline Black wildebeest & Connochaetes gnou & 150 & 2.00 & 2 & 2 & 4.75 & 81 & 3 & 1 & 47.98 \\
\hline Blue wildebeest & Connochaetes taurinus & 216 & 1.79 & 53 & 1,2 & 4.94 & 90 & 3 & 1 & 61.61 \\
\hline Hartebeest & Alcelaphus buselaphus & 136 & 1.89 & 76 & 1 & 5.23 & 97 & 3 & 1 & 93.92 \\
\hline Tsessebe & Damaliscus lunatus & 150 & 2.60 & 5 & 1 & 5.10 & 99 & 3 & 1 & 79.47 \\
\hline Takin & Budorcas taxicolor & 250 & 0.71 & 38 & 1 & 3.42 & 5 & 7 & 1 & 129.45 \\
\hline Bighorn sheep & Ovis canadensis & 59 & 0.72 & 29 & 1 & 4.11 & 67 & 3 & 1 & 27.23 \\
\hline Alpine ibex & Capra ibex & 87 & 0.69 & 234 & 1,2 & 4.71 & 60 & 3 & 1 & 87.78 \\
\hline Mainland serow & Capricornis sumatraensis & 102 & 0.64 & 22 & 1 & 3.39 & 3 & 8 & 2 & 227.32 \\
\hline Musk ox & Ovibos moschatus & 305 & 0.66 & 169 & 1,2 & 3.69 & 62 & 3 & 1 & 15.78 \\
\hline Waterbuck & Kobus ellipsiprymnus & 160.5 & 1.07 & 28 & 1,2 & 3.47 & 80 & 3 & 1 & 92 \\
\hline Lechwe & Kobus leche & 87 & 1.00 & 3 & 2 & 3.63 & 95 & 3 & 1 & 84.65 \\
\hline Kob & Kobus kob & 58 & 1.00 & 8 & 2 & 3.72 & 95 & 3 & 1 & 106.52 \\
\hline Southern reedbuck & Redunca arundinum & 62 & 1.00 & 1 & 2 & 3.59 & 95 & 5 & 2 & 86.11 \\
\hline Mountain reedbuck & Redunca fulvorufula & 26 & 1.17 & 64 & 1,2 & 3.79 & 99 & 3 & 1 & 66.93 \\
\hline Impala & Aepyceros melampus & 53 & 0.98 & 58 & 1,2 & 4.89 & 60 & 3 & 1 & 73.05 \\
\hline Oribi & Ourebia ourebi & 13 & 0.78 & 212 & 1,2 & 3.80 & 48.5 & 9 & 1 & 87.92 \\
\hline Steenbok & Raphicerus campestris & 11.8 & 1.20 & 10 & 2 & 3.44 & 10 & 9 & 1 & 52.18 \\
\hline Cape grysbok & Raphicerus melanotis & 10.6 & 1.00 & 6 & 2 & 2.64 & 30 & 5 & 2 & 33.18 \\
\hline Klipspringer & Oreotragus oreotragus & 12.8 & 1.00 & 1 & 2 & 3.82 & 5 & 3 & 1 & 66.5 \\
\hline Springbok & Antidorcas marsupialis & 39.1 & 0.37 & 27 & 1,2 & 4.89 & 30 & 3 & 1 & 24 \\
\hline Grant's gazelle & Gazella granti & 50 & 0.65 & 17 & 1 & 3.45 & 50 & 3 & 1 & 58.07 \\
\hline Gerenuk & Litocranius walleri & 34.7 & 0.87 & 99 & 1,2 & 1.32 & 0 & 3 & 1 & 40.53 \\
\hline Dibatag & Ammodorcas clarkei & 28 & 0.71 & 7 & 1 & 2.23 & 10 & 5 & 1 & 17.16 \\
\hline Saiga & Saiga tatarica & 36.4 & 1.60 & 5 & 1 & 5.29 & 26 & 3 & 1 & 19.21 \\
\hline Roe deer & Capreolus capreolus & 23.40 & 0.55 & 295 & 1,2 & 1.49 & 9 & 3 & 3 & 55.04 \\
\hline Moose & Alces alces & 400.5 & 0.98 & 230 & 1,2 & 1.34 & 2 & 3 & 3 & 33.59 \\
\hline Reindeer & Rangifer tarandus & 145 & 1.96 & 27 & 2 & 1.52 & 36 & 3 & 2 & 29.21 \\
\hline Pampas deer & Ozotoceros bezoarticus & 38 & 0.84 & 146 & 2 & 2.12 & 81 & 3 & 1 & 110.35 \\
\hline Red brocket & Mazama americana & 22.8 & 0.93 & 114 & 2 & 1.30 & 1 & 3 & 3 & 149.07 \\
\hline Marsh Deer & Blastocerus dichotomus & 96 & 0.73 & 26 & 2 & 1.49 & 24 & 10 & 1 & 121.57 \\
\hline Mule deer & Odocoileus hemionus & 74 & 0.49 & 170 & 1,2 & 1.59 & 11 & 3 & 2 & 38.76 \\
\hline Whlite-tailed deer & Odocoileus virginianus & 62 & 0.60 & 92 & 1,2 & 1.23 & 9 & 3 & 2 & 80.45 \\
\hline Axis deer & Axis axis & 55 & 1.45 & 49 & 1,2 & 2.81 & 70 & 3 & 1 & 96.14 \\
\hline Hog deer & Axis porcinus & 37.4 & 1.17 & 24 & 1 & 2.53 & 50 & 3 & 2 & 136.98 \\
\hline Wapiti & Cervus elaphus canadensis & 325 & 0.52 & 42 & 1,2 & 1.96 & 47 & 3 & 3 & 44.42 \\
\hline Red deer & Cervus elaphus scotticus & 153 & 0.83 & 6 & 2 & 2.11 & 47 & 3 & 2 & 44.42 \\
\hline Barasingha & Cervus duvaucelii & 183 & 1.80 & 50 & 1 & 2.85 & 75 & 3 & 2 & 101.07 \\
\hline Sambar deer & Cervus unicolor & 188 & 0.98 & 66 & 1,2 & 2.20 & 50 & 3 & 2 & 152.82 \\
\hline Pronghorn & Antilocapra americana & 50 & 0.37 & 43 & 1 & 4.61 & 15 & 3 & 1 & 29.88 \\
\hline
\end{tabular}


Table 1. (Continued)

\begin{tabular}{|c|c|c|c|c|c|c|c|c|c|c|}
\hline \multirow[b]{2}{*}{ Species } & & \multirow{2}{*}{$\begin{array}{l}\mathrm{BM} \\
\mathrm{kg}\end{array}$} & \multicolumn{3}{|c|}{ Mesowear } & \multirow[t]{2}{*}{$\mathrm{HI}$} & \multicolumn{2}{|l|}{ Grass } & \multirow[t]{2}{*}{$\mathrm{HAB}$} & \multirow{2}{*}{$\begin{array}{l}\text { PREC } \\
\mathrm{mm}\end{array}$} \\
\hline & & & MS & $n$ & Source & & $\%$ & Source & & \\
\hline Giraffe & Giraffa camelopardalis & 800 & 0.41 & 103 & 1,2 & 1.20 & 0 & 3 & 1 & 64.96 \\
\hline Okapi & Okapia johnstoni & 263 & 0.11 & 9 & 1,2 & 1.18 & 0 & 3 & 3 & 143.9 \\
\hline Water chevrotain & Hyemoschus aquaticus & 10.8 & 0.83 & 18 & 1 & 1.30 & 0 & 11 & 3 & 155.16 \\
\hline Spotted chevrotain & Moschiola meminna & 4 & 0.67 & 6 & 2 & 1.72 & 0 & 12 & 3 & 100.68 \\
\hline Lesser mouse deer & Tragulus javanicus & 3 & 0.43 & 14 & 2 & 1.47 & 0 & 3 & 3 & 169.24 \\
\hline Greater mouse deer & Tragulus napu & 6 & 0.94 & 16 & 2 & 1.67 & 0 & 3 & 3 & 233.98 \\
\hline Dromedary & Camelus dromedarius & 415 & 0.70 & 20 & 1,2 & 2.52 & 20 & 4 & 1 & 17.2 \\
\hline Guanaco & Lama guanicoe & 110 & 0.66 & 32 & 1 & 3.46 & 42.3 & 13 & 1 & 26.12 \\
\hline Vicugna & Vicugna vicugna & 75 & 0.91 & 11 & 2 & 3.65 & 69.3 & 14 & 1 & 60.49 \\
\hline White rhinoceros & Ceratotherium simum & 1600 & 3.08 & 24 & 1 & 3.90 & 95 & 4 & 1 & 60.61 \\
\hline Black rhinoceros & Diceros bicornis & 1100 & 0.08 & 37 & 1,2 & 2.24 & 5 & 4 & 2 & 70.41 \\
\hline Sumatran rhinoceros & Dicerorhinus sumatrensis & 800 & 0.25 & 8 & 1,2 & 1.67 & 0 & 15 & 3 & 238.66 \\
\hline Plains zebra & Equus quagga & 250 & 1.95 & 1001 & 2 & 5.83 & 90 & 16 & 1 & 75.72 \\
\hline Mountain zebra & Equus zebra & 281 & 2.23 & 640 & 2 & 7.06 & 80 & 17 & 1 & 19.95 \\
\hline Grevy's zebra & Equus grevyi & 400 & 2.38 & 149 & 1,2 & 5.80 & 100 & 18 & 1 & 50.35 \\
\hline African wild ass & Equus africanus & 220 & 1.67 & 15 & 2 & 8.73 & 50 & 19 & 1 & 40.53 \\
\hline Asian wild ass & Equus hemionus & 260 & 1.64 & 290 & 2 & 5.79 & 97 & 20 & 1 & 21.11 \\
\hline Wild horse & Equus ferus przewalskii & 350 & 1.56 & 50 & 2 & 5.70 & 90 & 4 & 1 & 36.44 \\
\hline Western tree hyrax & Dendrohyrax dorsalis & 4 & 0.93 & 28 & 1 & 1.53 & 0 & 21 & 2 & 151.82 \\
\hline Yellow-spotted rock hyrax & Heterohyrax brucei & 2 & 1.45 & 11 & 1 & 1.52 & 0 & 22 & 1 & 61.08 \\
\hline Rock hyrax & Procavia capensis & 3.8 & 1.58 & 24 & 1 & 1.69 & 67.5 & 23 & 1 & 64.24 \\
\hline
\end{tabular}

BM, body mass from (Mendoza et al. 2002). n, number of individuals used for dental data, MS, mesowear score from 1 (Fortelius \& Solounias 2000) and 2 (dataset of first author). \% grass in the natural diet taken from the literature 3 (Müller et al. 2011), 4 (Steuer et al. 2010 ), 5 (Gagnon \& Chew 2000), 6 (Cerling et al. 2003, Sponheimer et al. 2003, Codron et al. 2007), 7 (Schaller et al. 1986), 8 (Ochiai 1999; C. crispus), 9 (Clauss et al. 2009), 10 (Tomas \& Salis 2000), 11 (Dubost 1984), 12 (estimated based on other tragulids), 13 (Bahamonde et al. 1986, Raedeke \& Simonetti 1988, Puig et al. 2001, Cortés et al. 2003), 14 (Borgnia et al. 2010, Mosca Torres \& Puig 2010), 15 (Groves \& Kurt 1972), 16 (Grubb 1981 ), 17 (estimate based on Grobler 1983), 18 (Klingel 1969), 19 (estimate based on Grinder et al. 2006), 20 (Harris \& Miller 1995), 21 (Milner \& Harris 1999$), 22$ (Turner \& Watson 1965), 23 (Olds \& Shoshani 1982).

Habitat categories ( 1 = open, 2 = intermediate, 3 = closed) from Mendoza and Palmqvist (2008).

Mean annual precipitation at the centre of the species' geographical distribution from Jones et al. (2009).

species is estimated based on these measurements. The inclusion of MS as a covariable (OLS: $P<0.001$, PGLS: $P=0.001$ ) increased the $r^{2}$ of the overall relationship between \%grass (dependent variable) and HI (OLS: adjusted $r^{2}=0.50$, compared to $r^{2}=0.40$ without MS as a covariable). In contrast, MS did not contribute significantly (OLS: $P=0.762$, PGLS: $P=0.587)$ to the relationship between PREC (dependent variable) and HI (OLS: adjusted $r^{2}=0.13$ as compared to $r^{2}=0.14$ without MS as a covariable).

\section{DISCUSSION}

Our results indicate that the MS is related to the diet, but not to other components of the habitat. Any conclusion about habitat taken from the MS will therefore be due to the character of the diet itself. In contrast, the HI represents a signal that includes a habitat effect that exists in addition to that of the natural diet. A dietary reconstruction based on $\mathrm{HI}$ will therefore gain in accuracy if the MS information is used in addition (cf. also Fraser \& Theodor 2011).
This finding could be due to two mutually exclusive reasons. On the one hand, there is the difference between the measurement of an actual event (causing tooth wear, as quantified in the MS) and the measurement of the evolutionary acquisition of an adaptation (as quantified in the HI). The HI could reflect tooth wear not as it is today, but as it occurred in some distant past, or during an evolutionary history of shifting conditions and diets, as in the Neogene radiation of hypsodont equids (Mihlbachler et al. 2011). Whether this can explain the observed mismatch of MS and HI depends on whether one considers the obvious corresponding discrepancy between past and present tooth wear not as random but as a systematic function of habitat change. Under the historical mismatch scenario, the systematic habitat effect shown in Fig. 7 can only be explained by a systematic reduction of tooth wear in open habitats from the original evolution of hypsodonty (large HI) until the present - a hypothesis that appears unlikely. If instead we assume that hypsodonty today generally reflects conditions of rapid tooth wear to which it originally evolved, then we must conclude 


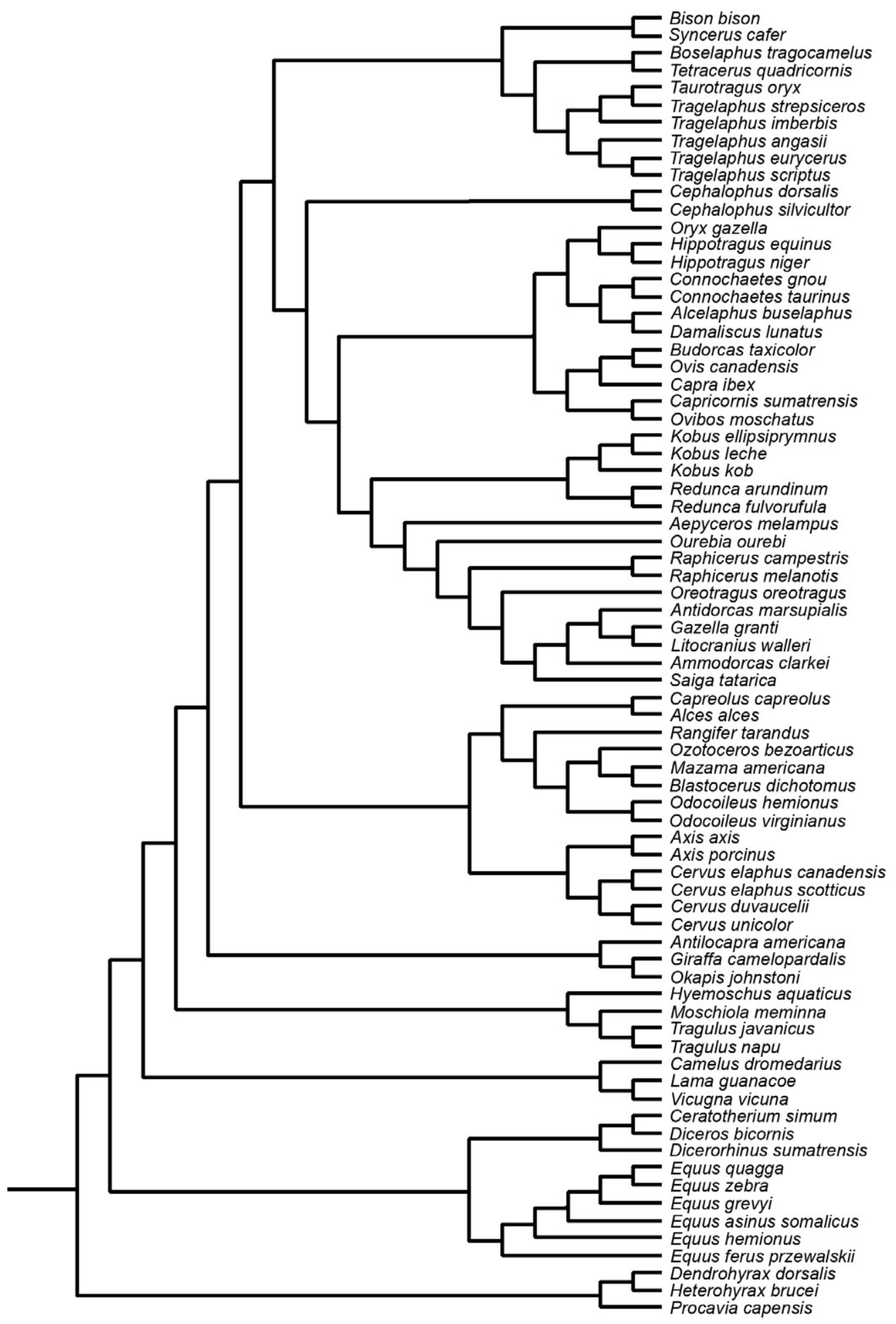

Fig. 3. Phylogenetic tree used as the basis of the phylogenetic generalized least squares approach in this study. 
(a)

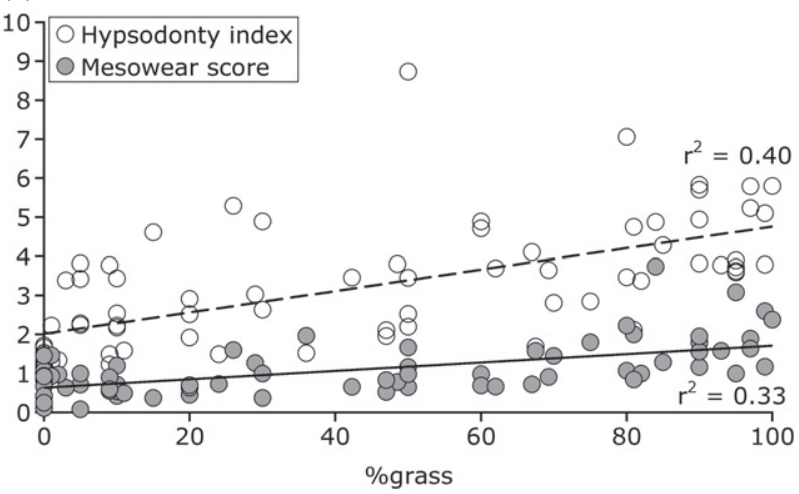

(b)

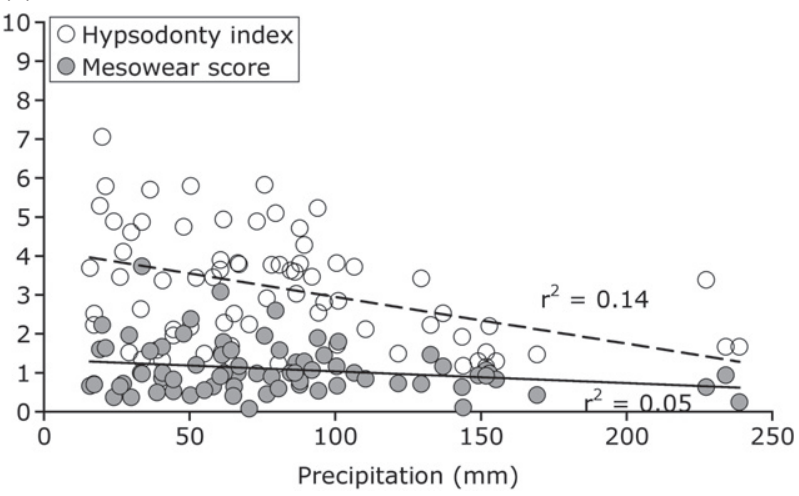

Fig. 4. Relationships between (a) the percentage grass in the natural diet (\%grass) and (b) the mean annual precipitation at the centre of a species' distribution, and both hypsodonty index and mesowear score in 75 mammalian herbivores. Data from Table 1.

that the MS does not capture the full effect of all aspects of tooth wear, but only of that part predominantly related to diet and its intrinsic abrasives. The evident resulting question is: what other abrasives exist that are in fact not related to the diet but also do not affect the MS? In order to develop a theory, a look at the outliers in Fig. 5b is instructive.

Those outliers that have a comparatively low HI for the degree of wear expressed in the MS are cervid species. These cases support the hypothesis presented by Heywood (2010): due to their molar morphology, cervids cannot evolve the same degree of hypsodonty as bovids. Perhaps the most prominent outlier in the MS-HI relationship is the pronghorn, with a very high HI but a very low MS (Fortelius \& Solounias 2000). Both Semprebon and Rivals (2007) and Damuth and Janis (2011) explain that the natural diet of the pronghorn, with its very low percentage of grass, does not match the expectation one has based on the high HI. Semprebon and Rivals (2007) explain this outlier with the time-lag argument, assuming that the switch from a grass-rich to a browse-rich diet must have been a comparatively recent event in the history of the species. In contrast, Damuth and Janis (2011) explain it as a result of the high rate of soil ingestion which has been measured in pronghorns, of similar magnitude to that in similarly hypsodont grazers (domestic horse and cattle) in the same habitat. Semprebon and Rivals (2007) had also considered but rejected this hypothesis because it is, in their view, not compatible with the browsing mesowear signal characteristic of the species; these authors imply that the ingestion of soil should lead to a distinct change of the molar wear facets and thus the MS.

The data in Fig. 5b suggest that the pronghorn is no individual peculiarity, but that springbok, impala and ibex may represent similar cases. Whether these species ingest a sufficiently high amount of dust, grit or soil in their natural environment to explain their high level of hypsodonty remains to be demonstrated. Hummel et al. (2011) demonstrated that the impala matches the overall pattern of hypsodonty and faecal silica levels, suggesting that - similar to the pronghorn - abrasive elements are ingested in amounts one would expect based on the HI, but which are not reflected in the MS. Given that ibex and springbok browse at low feeding height, and in dry habitats (van Zyl 1965, Bigalke 1972, Davies et al. 1986, Milton et al. 1992, Martínez

(a)

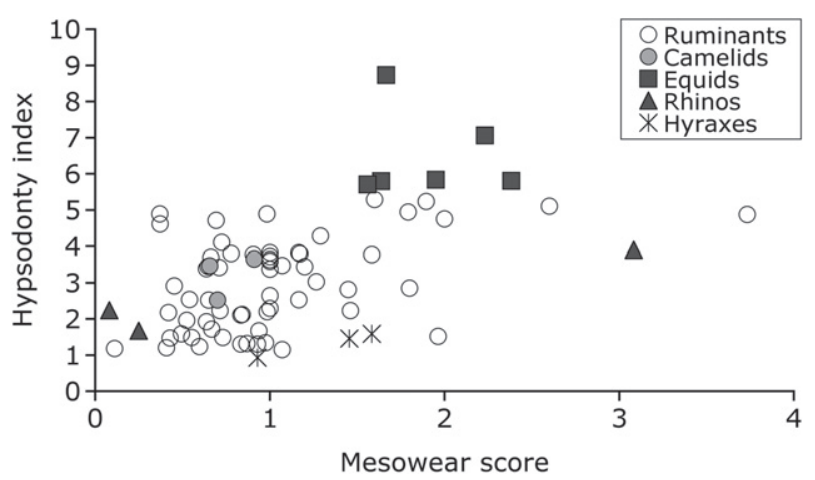

(b)

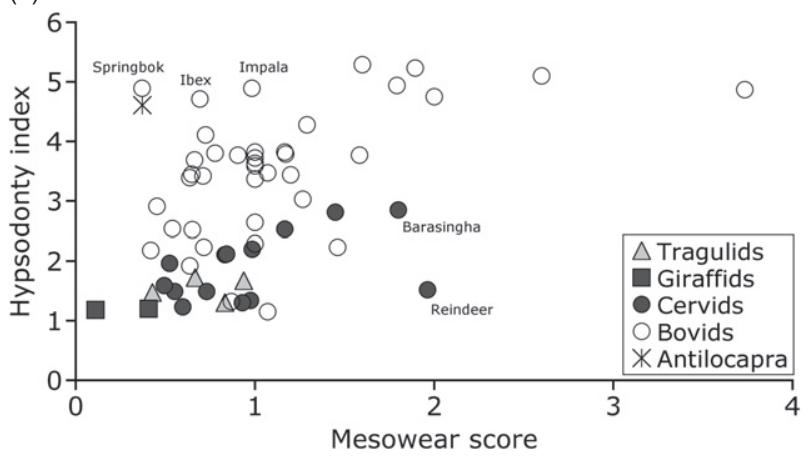

Fig. 5. Relationships between the mesowear score and the hypsodonty index in (a) 75 mammalian herbivores and (b) 63 ruminant species. Data from Table 1 
(a)

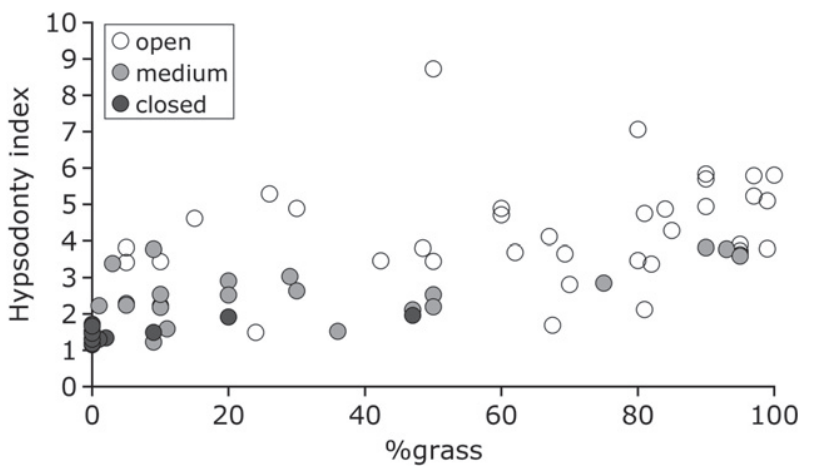

(b)

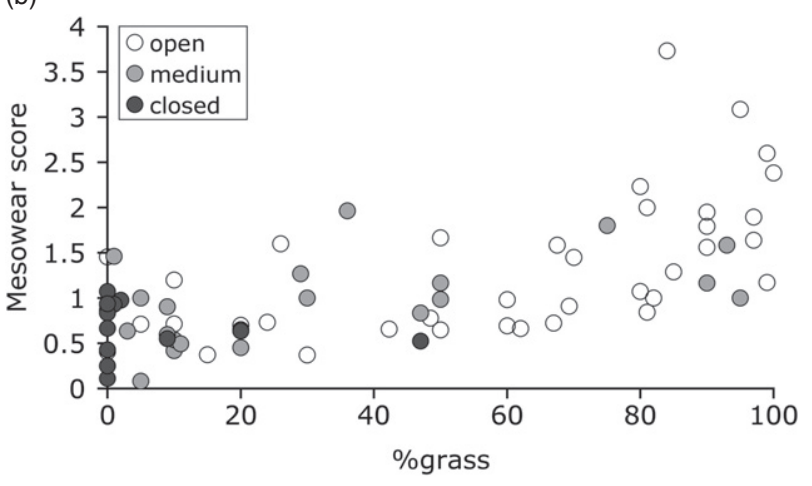

Fig. 6. Relationship between the percentage grass in the natural diet (\%grass) and (a) the hypsodonty index and (b) the mesowear score in 75 mammalian herbivores, illustrating the additional effect of habitat category in (a) and the lack of such an effect in (b). Data from Table 1.

2000), a similar mechanism could be expected in these species that needs to be substantiated in more detailed studies. Studies of these species could particularly enable us to understand extrinsic vs. intrinsic properties of food that influence tooth wear, and evolutionary patterns in ungulate dentition.

These reflections lead to a concept of tooth wear where intrinsic abrasives determine the pattern of relative facet development (MS), while extrinsic abrasives simply remove tooth material without affecting the wear pattern. This concept appears difficult to accept intuitively because we think of 'soil ingestion' as the ingestion of coarse, sand-like material that has large grain sizes and can lead to massive and even pathological wear, as reported from sheep at pastures in New Zealand (Healy \& Ludwig 1965, Ludwig et al. 1966) and from zoo animals fed on sandy soil (Martin Jurado et al. 2008). Such wear, considering the enormous documented changes to tooth structure, must also affect the MS. The problem would disappear, however, if the majority of wear induced by particles extrinsic to the food material did not stem from such large-grain abrasives, but from much finer dust particles that did not affect the morphology of wear facets as recognisable 'abrasion'. This would result in more evenly distributed abrasion of dental tissues than would phytoliths, which in particular would abrade dental tissues in places where interdental spaces become very narrow during mastication. If this view was correct, we would expect phytoliths - as the major intrinsic abrasive - to be of a distinctively larger grain size and/or greater compactness than the extrinsic abrasives adhering to plants in the form of dust.

Phytolith dimensions vary enormously, between 5 to $250 \mu \mathrm{m}$ in diameter or more, with a range of 5-60 $\mu \mathrm{m}$ and a mean of $25 \mu \mathrm{m}$ for grasslands (reviewed in Strömberg 2004). Dust particle sizes cover this whole range: diameters of $<5 \mu \mathrm{m}$ for particles in long-distance dust deposits and $20-40 \mu \mathrm{m}$ for particles in dust deposits from regional sources are reported in one publication (e.g. McTainsh et al. 1997). Evidently, empirical data on the amount and properties of phytoliths and on extrinsic particles adhering to forage ingested by herbivores are required to pursue our hypothesis. Our crude categorical habitat classification might also be improved by a more precise set of climatic indicators, including not only precipitation but also geological surface processes, volcanism and other factors related to the occurrence of extrinsic abrasives.

The implications of the concept proposed here could be tested empirically. Wear rates should increase in general in dusty environments without affecting the MS, and large extrinsic particles should be absent from the diet and hence faeces of herbivores (i.e. the largest silicaceous objects in faeces should be phytoliths). In experiments, overall tooth wear rate should be proportional to the number of abrasive particles per unit food, to the degree to which the particles are impacted in the dental tissues (food toughness and chewing force) and to the number of chewing cycles per unit nutrition (food quality). Wear facet formation and morphology should be independent of those factors, and should instead depend on the distribution of effective abra-

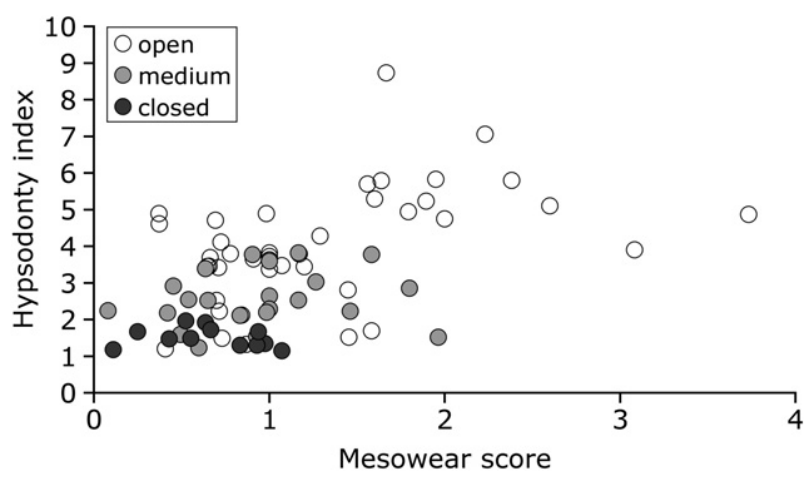

Fig. 7. Relationship between the mesowear score and the hypsodonty index in 75 mammalian herbivores, illustrating the additional effect of habitat category. Data from Table 1. 
sive particle size, a measure ideally including not only the maximum dimension but also the hardness and fracture behaviour of particles. To conclude, we propose that the apparent discrepancy between HI and MS data suggests a major role in naturally occurring tooth wear for external abrasives of very small size. This hypothesis is currently being explored experimentally.

\section{ACKNOWLEDGEMENTS}

This research was supported by the Deutsche Forschungsgemeinschaft (DFG, German Research Foundation) and is publication no. 33 of the DFG Research Unit 771 'Function and enhanced efficiency in the mammalian dentition phylogenetic and ontogenetic impact on the masticatory apparatus' (TMK, ES, JH). ES was further supported by the SYNTHESYS (AT-TAF-4763), COBICE (DK-TAF), DAAD (PhD short term fellowship) and DFG KA1525/4-1, 4-2 grants. MF and MC were supported by the National Evolutionary Synthesis Center (NESCent), NSF \#EF-0905606. We acknowledge the generous support and access to the specimens investigated for this study provided by the collections of the Museum für Naturkunde Berlin, Naturhistorisches Museum Bern, Zoological Museum Copenhagen, Bayerische Staatssammlung München, Museum für Haustierkunde Julius-Kühn Halle/Saale, Zoologisches Museum Hamburg, Naturalis Leiden, British Museum of Natural History London, Zoological Museum Moscow, American Museum of Natural History New York, Etosha National Park Okaukuejo, Muséum national de l'Histoire naturelle Paris, Transvaal Museum Pretoria, Museum of Natural History Rio de Janeiro, Zoological Museum São Paulo, Russian Academy of Science St. Petersburg, The Swedish Museum of Natural History, National Museum Windhoek, Smithsonian Museum Washington, Naturhistorisches Museum Wien, and the Private Collection of K. Hecker in Pretoria (Nico van Rooyen Taxidermy).

\section{REFERENCES}

Bahamonde N, Martin SK, Sbriller AP (1986) Diet of guanaco and red deer in Neuquen Province, Argentina. Journal of Range Management 39: 22-24.

Bigalke RC (1972) Observations on the behavior and feeding habits of the springbok (Antidorcas marsupialis). Zoologica Africana 7: 333-359.

Bininda-Emonds ORP, Cardillo M, Jones KE, MacPhee RDE, Beck RMD, Grenyer R et al. (2007) The delayed rise of present-day mammals. Nature 446: 507-512.

Borgnia M, Vilá BL, Cassini MH (2010) Foraging ecology of vicuña (Vicugna vicugna) in dry Puna of Argentina. Small Ruminant Research 88: 44-53.
Cerling TE, Harris JM, Passey BH (2003) Diets of East African Bovidae based on stable isotope analysis. Journal of Mammalogy 84: 456-470.

Clauss M, Hofmann RR, Fickel J, Streich WJ, Hummel J (2009) The intraruminal papillation gradient in wild ruminants of different feeding types: implications for rumen physiology. Journal of Morphology 270: 929-942.

Clauss M, Kaiser T, Hummel J (2008) The morphophysiological adaptations of browsing and grazing mammals. In: Gordon IJ, Prins HHT (eds) The Ecology of Browsing and Grazing, 47-88. Springer, Heidelberg, Germany.

Codron D, Brink JS, Rossouw L, Clauss M, Codron J, Lee-Thorp JA et al. (2008) Functional differentiation of African grazing ruminants: an example of specialized adaptations to very small changes in diet. Biological Journal of the Linnaean Society 94: 755-764.

Codron D, Lee-Thorp JA, Sponheimer M, Codron J, de Ruiter D, Brink JS (2007) Significance of diet type and diet quality for ecological diversity of African ungulates. Journal of Animal Ecology 76: 526-537.

Cortés A, Miranda E, Rau JR, Jiménez JE (2003) Feeding habits of guanacos (Lama guanicoe) in the high Andes of north-central Chile. Acta Theriologica 48: 229-237.

Damuth J, Fortelius M (2001) Reconstructing mean annual precipitation, based on mammalian dental morphology and local species richness. In: Agustí J, Oms O (eds) EEDEN Plenary Workshop on Late Miocene to Early Pliocene Environment and Ecosystems, 23-24. EEDEN Programm, European Science Foundation, Sabadell, Spain.

Damuth J, Janis CM (2011) On the relationship between hypsodonty and feeding ecology in ungulate mammals, and its utility in paleoecology. Biological Reviews 86: 733-758.

Damuth JD, Fortelius M, Andrews P, Badgley C, Hadley AE, Hixon $S$ et al. (2002) Reconstructing mean annual precipitation based on mammalian dental morphology and local species richness. Journal of Vertebrate Paleontology 22 (Suppl. 3): 48A.

Davies RAG, Botha P, Skinner JD (1986) Diet selected by springbok (Antidorcas marsupialis) and merino sheep (Ovis aries) during Karoo drought. Transactions of the Royal Society of South Africa 46: 165-176.

Dubost G (1984) Comparison of the diets of frugivorous forest ruminants of Gabon. Journal of Mammology 65: 298-316.

Eronen JT, Pulomäki K, Liu L, Lintulaakso K, Damuth J, Janis C et al. (2010a) Precipitation and large herbivorous mammals I: estimates from present-day communities. Evolutionary Ecology Research 12: 217-233.

Eronen JT, Pulomäki K, Liu L, Lintulaakso K, Damuth J, Janis C et al. (2010b) Precipitation and large herbivorous mammals II: application to fossil data. Evolutionary Ecology Research 12: 235-248.

Felsenstein J (1985) Phylogenies and the comparative method. The American Naturalist 125: 1-15. 
Fortelius M (1985) Ungulate cheek teeth: developmental, functional, and evolutionary interrelations. Acta Zoologica Fennica 180: 1-76.

Fortelius M (1987) A note on the scaling of dental wear. Evolutionary Theory 8: 73-75.

Fortelius M (1988) Isometric scaling of mammalian cheek teeth is also true metabolic scaling. In: Russel DE, Santoro J-P, Sigogneau-Russel D (eds) Teeth Revisited: Proceedings of the Viith International Symposium on Dental Morphology, Paris 1986. Mém. Mus. Natn. Hist. Nat., Paris (Série C) 53, 459-462, Paris, France.

Fortelius M, Eronen JT, Jernvall J, Pushkina D, Rinne J, Tesakov A et al. (2002) Fossil mammals resolve regional patterns of Eurasian climate change over 20 million years. Evolutionary Ecology Research 4: 1005-1016.

Fortelius M, Solounias N (2000) Functional characterization of ungulate molars using the abrasion-attrition wear gradient: a new method for reconstructing paleodiets. American Museum Novitates 3301: 1-36.

Fraser D, Theodor JM (2011) Comparing ungulate dietary proxies using discriminant function analysis. Journal of Morphology doi 10.1002/jmor.11001

Fritz J, Hummel J, Kienzle E, Arnold C, Nunn C, Clauss M (2009) Comparative chewing efficiency in mammalian herbivores. Oikos 118: 1623-1632.

Gagnon M, Chew AE (2000) Dietary preferences in extant African Bovidae. Journal of Mammalogy 81: 490-511.

Grinder MI, Krausman PR, Hoffmann RS (2006) Equus asinus. Mammalian Species 794: 1-9.

Grobler JH (1983) Feeding habits of the Cape Mountain zebra (Equus zebra zebra). Koedoe 26: 159-168.

Groves C, Kurt F (1972) Dicerorhinus sumatrensis. Mammalian Species 21: 1-6.

Grubb PJ (1981) Equus burchelli. Mammalian Species 157: 1-9.

Harris RB, Miller DJ (1995) Overlap in summer habitats and diets of Tibetan Plateau ungulates. Mammalia 59: 197-212.

Healy WB, Ludwig TG (1965) Wear of sheep's teeth: I. The role of ingested soil. New Zealand Journal of Agricultural Research 8: 737-752.

Heywood JJN (2010) Explaining patterns in modern ruminant diversity: contingency or constraint? Biological Journal of the Linnaean Society 99: 657-672.

Hummel J, Findeisen E, Südekum K-H, Ruf I, Kaiser TM, Bucher M et al. (2011) Another one bites the dust - faecal silica levels in large herbivores correlate with hypsodonty. Proceedings of the Royal Society of London. Series B. Biological Sciences 278: 1742-1747.

Janis CM (1988) An estimation of tooth volume and hypsodonty indices in ungulate mammals and the correlation of these factors with dietary preferences. In: Russell DE, Santoro J-P, Signogneau-Russell D (eds) Proceedings of the Teeth revisited. Proceedings of the VIIth International Symposium on Dental Morphology. Mémoires du Muséum national d'Histoire Naturelle, Paris (serie C), 367-387.
Janis CM, Fortelius M (1988) On the means whereby mammals achieve increased functional durability of their dentitions with special reference to limiting factors. Biological Reviews 63: 197-230.

Jones KE, Bielby J, Cardillo M, Fritz SA, O’Dell J, Orme CD et al. (2009) PanTHERIA: a species-level database of life history, ecology, and geography of extant and recently extinct mammals. Ecology 90: 2648. (Ecological Archives E2090-2184).

Kaiser TM (2011) Feeding ecology and niche partitioning of the Laetoli ungulate faunas. In: Harrison T (ed.) Paleontology and Geology of Laetoli: Human Evolution in Context. Vol. I: Geology, Geochronology, Paleoecology and Paleoenvironment, 329-354. Springer, Berlin, Germany.

Kaiser TM, Brasch J, Castell JC, Schulz E, Clauss M (2009) Tooth wear in captive wild ruminant species differs from that of free-ranging conspecifics. Mammalian Biology 74: 425-437.

Kaiser TM, Fickel J, Streich WJ, Hummel J, Clauss M (2010) Enamel ridge alignment in upper molars of ruminants in relation to their natural diet. Journal of Zoology 281: 12-25.

Kaiser TM, Schulz E (2006) Tooth wear gradients in zebras as an environmental proxy - a pilot study. Mitteilungen aus dem Hamburgischen Zoologischen Museum und Institut 103: 187-210.

Kaiser T, Solounias N, Fortelius M, Bernor RL, Schrenk F (2000) Tooth mesowear analysis on Hippotherium primigenium from the Vallesian Dinotheriensande (Germany) - a blind test study. Carolinea 58: 103-114.

Kaiser T, Rössner GE (2007) Dietary resource partitioning in ruminant communities of Miocene wetland and karst palaeoenvironments in Southern Germany. Palaeogeography, Palaeoclimatology, Palaeoecology 252: 424-439.

Klingel H (1969) Zur Soziologie des Grevy-Zebras. Zoologischer Anzeiger 33 (Suppl): 311-316.

Ludwig TG, Healy WB, Cutress TW (1966) Wear of sheep's teeth: III. Seasonal variation in wear and ingested soil. New Zealand Journal of Agricultural Research 9: 157-164.

Maddison WP, Maddison DR (2006) Mesquite: a modular system for evolutionary analysis. http://mesquiteproject.org

Martin Jurado O, Clauss M, Hatt JM (2008) Irregular tooth wear and longevity in captive wild ruminants: a pilot survey of necropsy reports. Journal of Zoo and Wildlife Medicine 39: 69-75.

Martínez T (2000) Diet selection by Spanish ibex in early summer in Sierra Nevada. Acta Theriologica 45: 335-346.

Martins E (2004) COMPARE, version 4.6. Computer programs for the statistical analysis of comparative data. Distributed by the author at http://compare.bio.indiana.edu/ Department of Biology, Indiana University, Bloomington, Indiana, USA.

Martins EP, Hansen TF (1997) Phylogenesis and the comperative method: a general approach to incorporating phylogenetic information into the analysis of interspecific data. The American Naturalist 149: 646-667.

McTainsh GH, Nickling WG, Lynch AW (1997) Dust deposition and particle size in Mali. West African Catena 29: 307-322. 
Mendoza M, Janis CM, Palmqvist P (2002) Characterizing complex craniodental patterns related to feeding behaviour in ungulates: a multivariate approach. Journal of Zoology London 258: 223-246.

Mendoza M, Palmqvist P (2008) Hypsodonty in ungulates: an adaptation for grass consumption or for foraging in open habitat? Journal of Zoology 274: 134-142.

Mihlbachler MC, Rivals F, Solounias N, Semprebon GM (2011) Dietary change and evolution of horses in North America. Science 331: 1178-1181.

Mihlbachler MC, Solounias N (2006) Coevolution of tooth crown height and diet in oreodonts (Merycoidodontidae, Artiodactyla) examined with phylogenetically independent contrasts. Journal of Mammalian Evolution 13: 11-36.

Milner JM, Harris S (1999) Activity patterns and feeding behaviour of the tree hyrax (Dendrohyrax arboreus) in the Parc National des Volcans, Rwanda. African Journal of Ecology 37: 267-280.

Milton SJ, Dean WRJ, Marincowitz CP (1992) Preferential utilization of pans by springbok (Antidorcas marsupialis). Journal of the Grassland Society of Southern Africa 9: 114-118.

Mosca Torres ME, Puig S (2010) Seasonal diet of vicuñas in the Los Andes protected area (Salta, Argentina): are they optimal foragers? Journal of Arid Environments 74: 450-457.

Müller DWH, Bingaman Lackey L, Streich WJ, Fickel J, Hatt J-M, Clauss M (2011) Mating system, feeding type and ex-situ conservation effort determine life expectancy in captive ruminants. Proceedings of the Royal Society of London. Series B. Biological Sciences 278: 2076-2080.

Ochiai K (1999) Diet of the Japanese serow (Capricornis crispus) on the Shimokita Peninsula, northern Japan, in reference to variations with a 16-year interval. Mammal Study 24: 91-102.

Olds N, Shoshani J (1982) Procavia capensis. Mammalian Species 171: 1-7.

Owen-Smith N (1988) Megaherbivores - the Influence of Very Large Body Size on Ecology. Cambridge University Press, Cambridge, UK.

Pagel M (1999) Inferring the historical patterns of biological evolution. Nature 401: 877-884.

Puig S, Videla F, Cona MI, Monge SA (2001) Use of food availability by guanacos (Lama guanicoe) and livestock in Northern Patagonia (Mendoza, Argentina). Journal of Arid Environments 47: 291-308.

Raedeke KJ, Simonetti JA (1988) Food habits of Lama guanicoe in the Atacama desert of northern Chile. Journal of Mammalogy 69: 198-201.

Reilly SM, McBrayer LD, White TD (2001) Prey processing in amniotes: biomechanical and behavioral patterns of food reduction. Comparative Biochemistry and Physiology A 128: 397-415.

Rivals F, Mihlbachler MC, Solounias N (2007) Effect of ontogenetic-age distribution in fossil and modern samples on the interpretation of ungulate paleodiets using the mesowear method. Journal of Vertebrate Paleontology 27: 763-767.
Rivals F, Schulz E, Kaiser T (2008) Climate-related dietary diversity of the ungulate faunas from the middle Pleistocene succession (OIS 14-12) at the Caune d l'Arago (France). Paleobiology 34: 117-127.

Rivals F, Semprebon GM (2006) A comparison of the dietary habits of a large sample of the Pleistocene pronghorn (Stockoceros onusrosagris) from the Papago Springs cave in Arizona to the modern Antilocapra americana. Journal of Vertebrate Paleontology 26: 495-500.

Rohlf F (2001) Comparative methods for the analysis of continuous variables: geometric interpretations. Evolution 55: 2143-2160.

Sanson GD, Kerr SA, Gross KA (2007) Do silica phytoliths really wear mammalian teeth? Journal of Archaeological Science 34: 526-531.

Schaller GB, Teng Q, Pan W, Qin Z, Wang X, Hu J et al. (1986) Feeding behavior of Sichuan takin (Budorcas taxicolor). Mammalia 50: 311-322.

Semprebon G, Rivals F (2007) Was grass more prevalent in the pronghorn past? An assessment of the dietary adaptations of Miocene to recent Antilocapridae. Palaeogeography, Palaeoclimatology, Palaeoecology 253: 332-347.

Solounias N, Fortelius M, Freeman P (1994) Molar wear rates in ruminants: a new approach. Annales Zoologici Fennici 31: 219-227.

Sponheimer M, Lee-Thorp JA, DeRuiter D, Smith JM, Van der Merwe NJ, Reed K et al. (2003) Diets of Southern African Bovidae: stable isotope evidence. Journal of Mammalogy 84: 471-479.

Steuer P, Clauss M, Südekum K-H, Hatt J-M, Silinski S, Klomburg S et al. (2010) Comparative investigations on digestion in grazing (Ceratotherium simum) and browsing (Diceros bicornis) rhinoceroses. Comparative Biochemistry and Physiology A 156: 380-388.

Strömberg CAE (2004) Using phytolith assemblages to reconstruct the origin and spread of grass-dominated habitats in the great plains of North America during the late Eocene to early Miocene. Paleogeography, Paleoclimatology, Paleoecology 207: 239- 275.

Strömberg CAE (2006) Evolution of hypsodonty in equids: testing a hypothesis of adaptation. Paleobiology 32 : 236-258.

Tomas WM, Salis SM (2000) Diet of the marsh deer (Blastocerus dichotomus) in the Pantanal wetland, Brazil. Studies of Neotropical Fauna and Environment 35: 165-172.

Turner MIM, Watson RM (1965) An introductory study on the ecology of hyrax (Dendrohyrax brucei and Procavia johnstoni) in the Serengeti National Park. East African Wildlife Journal 3: 49-60.

Van Valen L (1960) A functional index of hypsodonty. Evolutionary Ecology Research 14: 531-532.

van Zyl JHM (1965) The vegetation of the S.A. Lombard Nature Reserve and its utilization by certain antelopes. Zoologica Africana 1: 55-71. 